\title{
Investigation on the Efficiency of International Tourism Industry in Sri Lanka: An Application of DEA Production Frontier Approach
}

Nisantha Kurukulasooriy Ajith ${ }^{1}$ and Erandathie Irangika Lelwala ${ }^{2}$

\section{Abstract}

This study attempted at evaluating the performance of international tourism industry in Sri Lanka in terms of technical efficiency with the use of nonparametric production frontier approach which is based on data envelopment analysis (DEA). Accordingly, different DEA specifications were employed related to different combinations of outcomes of tourism industry. Official tourism receipts, direct employment generation and foreign guest nights were considered as outputs while number of beds / number of hotel rooms, international tourist arrivals and all items tourist price index was treated as inputs into the different models. Finally, a single model was estimated amalgamating all three different outputs into one model for the sample period. Findings revealed that the tourism industry has been operating inefficiently within the last three decades and have possibilities for further improvements altering the inputs of the industry since DEA efficiency scores are relative measures. It further revealed that investment on construction work such as construction of more hotels is wastage of resources and some strategies should be formulated to increase the room occupancy rate and control inflation on tourism activities in terms of the tourist prices. Marketing or promotional strategies need to be initiated to increase international visitor arrivals as well as average room occupancy rates since the industry is prevailing increasing returns to scale efficiency.

\author{
${ }^{1,2}$ Department of \\ Economics, University of \\ Ruhuna, Sri Lanka \\ ${ }^{1}$ nisantha.ajith@gmail.com
}

Keywords: Data envelopment analysis, efficiency, international tourism, production frontiers, Sri Lanka 


\section{Original Article}

\section{INTRODUCTION}

Tourism has become one of the largest and fastest growing industries in the world and has documented as one of the key sources of positive growth for diverse of economies around the world. Rising the importance of tourism industry and it's expected positive impacts on economic growth, tourism policy plays a vital role in development strategies of many countries and regions. Sri Lankan tourism occupies the third position as one of the largest foreign exchange earners with the contribution of 14.8 per cent by 2017 (SLTDA, 2017). Tourism is also important in terms of generating of government revenue, employment generation, regional development and initiation of new business opportunities (Tisdell, 2013). Therefore, a Sri Lankan government considers the tourism industry as an engine of economic growth and consequently has adopted various activities to improve the performance of the industry. The goal of the Sri Lanka Tourism Development Authority (SLTDA) is to promote Sri Lanka and its tourism resources to the world. SLTDA has focused building market confidence, ensuring profitability and developing investor confidence in terms of developing existing markets while struggling to find new markets. Tourism industry requires a huge investment to reach the goals. The information such as level of efficiency, returns to scale etc. on the performance of the industry are vital in this context regard.

Almost all the previous studies on performance of tourism were carried out for the evaluation of tourist hotels (Barros \& Mascaren has, 2005; Hwang and Chang, 2003) and tourist destinations (Cracolicia et al. (2006) while some recent studies paid the attention to evaluate the overall performance of tourism industry as a whole (Hadad et al. 2012; Soysal-Kurt, 2017: Bayrak \& Bahar, 2018). Tourism literature in Sri Lanka is mainly attempting to evaluate the forecasting of potential arrivals (Kurukulasooriya, 2011; Kurukulasooriya and Lelwala, 2014; Konarasinghe, 2016; Ishara and Wijekoon, 2017; Dharsana and Kurukulasooriya, 2018; Nyoni, 2019; Roshan and Jahufer, 2019) and still there is no such an attempt to discuss the performance of tourism industry in Sri Lanka and thus the current study addresses this research issue with the aim of filling this knowledge gap in the tourism sector in Sri Lanka. Accordingly, the key objective of this research is to investigate the performance in terms of technical efficiency of the industry while providing an analytical framework based on nonparametric DEA frontiers. Finally, it provides some valuable information which will help in policy arena in tourism. 


\section{LITERATURE REVIEW}

The DEA approach has been applied in the literature to evaluate the tourism efficiency (Anderson et al., 2000; Barros, 2004; Barros \& Mascarenhas, 2005; Reynolds, 2003). Anderson et al., (2000) employed DEA to analyse the efficiency and its determinants of 48 hotels in the US. Full-time equivalent employees, the number of rooms, total gaming-related expenses, total food and beverage expenses, and other expenses were the inputs to the DEA model while total revenue was employed as the output variable. Findings showed that the hotel industry was inefficient, with a mean overall efficiency measure of approximately 42 per cent.

The analysis of efficiency of tourism industry using DEA or other parametric methods is limited to a few of empirical studies in extant literature. Majority of studies focused on the analysis of micro-units such as hotels, corporate travel departments (Hadad et al. 2012). Hwang, Chang and Hwang (2003) have measured the managerial performance and the efficiency changes of 45 hotels from 1994 to 1998 using DEA and the Malmquist productivity index. They have concluded that a significant difference in efficiency changes is due to the differences of sources of customers and management styles practiced in hotels. The technical and allocative efficiency of 43 hotels in Portugal have investigated by Barros and Mascaren has (2005) using the
DEA with 3 inputs and 3 outputs. An overview of efficiency analysis of restaurant industry can be found in Reynolds (2003).

Cracolici et al. (2006) have employed DEA and Malmquist productivity index to estimate a visitor production function in Italian tourist destinations. They have employed DEA taking the main advantage of not requiring any rigorous assumptions concerning the production technology and its capability to easily accommodate multiple inputs and outputs. Pulina et al. (2010), have employed DEA Window analysis to analyse the efficiency of hotels across all of the 20 regions in Italy. A modified two-stage model was employed by Huang, et al., (2011) to evaluate productive efficiency, occupancy, and catering service effectiveness in Taiwan's international tourist hotels. Their findings showed that 39 hotels were performing well while 25 hotels were inefficient. These inefficiencies were due to some factors that are related to the operational behavior of the hotels. The performance of tourism industry in Portuguese was investigated by Oliveira et al. (2013) employing the DEA method to examine technical efficiency of a sample of 84 hotels during 2005-2007. According to findings, star rating is not a significant determinant of efficiency but location and the existence of golf courses may have some relevance. 
Recently, researchers have changed their scope from micro to macro level studies in investigate the efficiency and productivity of tourism industry. Economic contributions and increasing competition in the global tourism market motivated researchers for such studies. Soysal-Kurt (2017) conducted macro level tourism efficiency study for European countries and have focused on the characteristics such as number of employees, tourism expenses, number of beds, tourism receipts, tourist arrivals, number of nights spent as inputs and outputs related to efficiency of tourism industry. The CCR-DEA approach was adopted for data form 29 high income and upper-middle income countries. Findings revealed that 16 countries were efficient and other 13 countries were inefficient.

Chaabouni (2019) has investigated tourism efficiency and its determinants using a two-stage double bootstrap approach for a global panel of 31 Chinese provinces over the period 2008-2013. In the first stage the Bias-corrected DEA efficiency scores were calculated by employing the smoothed homogeneous bootstrapped procedure (Simar \& Wilson, 2007). Those efficiency scores were then regressed on a set of explanatory variables using the double-truncated regression approach. Findings revealed that the tourism efficiency in China was low over the sample period. Further, trade openness, climate change and intensity of market competition have positive impact on tourism efficiency. The interesting results revealed several useful managerial insights and implications for tourism sector in China.

Some other methods have also employed for investigating the efficiency in tourism industry. One such rarely used method is the stochastic frontier analysis (SFA). Wang et al., (2007) have utilised a onestage stochastic frontier approach to measure the relative efficiency of 66 international tourist hotels in Taiwan during 1992-2002. The Malmquist productivity index has utilised to estimate the range and the cause of the productivity change. Wang et al. (2007) has used the four inputs; salaries, the price of food and beverage, the number of rooms, and other operating expenses, and the three outputs namely; number of rooms occupied, food and beverage revenue, and other operating revenue. The empirical results implemented through the government policy and able to expand domestic travel and tourism. The local government's other expenditures had a significantly positive effect on efficiency of international tourist hotels.

Chen (2007) has adopted a stochastic cost frontier to analyse the cost efficiency of 55 international tourist hotels in Taiwan. The study has used three inputs (labour, food and beverage, and materials) and one output (the total revenue) to measure 
hotel efficiency. According to the result, the factor of operation type not only can affect hotel efficiency significantly, but also can be used to analyse whether the efficiency of the chain hotels is higher than that of independent hotels. The applications of SFA are considerably limited in the context of efficiency of tourism industry due to two main reasons. First, SFA can occupy a single output while DEA has capacities to accommodate multiple outputs. Second, SFA requires rigorous assumptions on the production frontier where there are no such assumptions in DEA production frontiers.

Following these limitations of SFA, current study provides analytical framework for the assessment of performance of tourism industry using a non-parametric DEA method. The nonparametric DEA is based on Farrell's (1957) original work and later it was elaborated by Charnes et al. (1978) introducing CCR ${ }^{1}$ model, and then Banker et al. (1984) introduced the BCC $^{2}$ Model. A comprehensive treatment of methodology and empirical applications of DEA are given in Cooper et al. (2007), and Fried et al. (2008).

\footnotetext{
${ }^{1}$ CCR stands for the first names of inventors of the model: Charnes, Cooper and Rhodes (CCR)

${ }^{2} \mathrm{BCC}$ stands for the first names of inventors of the model: Banker, Charnes and Cooper (BCC)
}

\section{MATERIALS AND METHODS}

\section{Data and Variables}

The current study is entirely based on secondary data that are completely obtained from the annual statistical reports of Sri Lanka Tourism Development Authority (SLTDA) and annual reports of the Central Bank of Sri Lanka.

Table 1: Inputs and outputs for different DEA runs

\begin{tabular}{|c|c|}
\hline Inputs & Outputs \\
\hline $\begin{array}{ll}\text { - } & \text { Tourist price index } \\
\text { for all item } \\
\text { - Number of hotel } \\
\text { rooms } \\
\text { - } & \text { Number of beds } \\
\text { - Tourist arrivals }\end{array}$ & $\begin{array}{ll} & \text { Tourism } \\
\text { receipts } \\
\text { Tourist } \\
\text { nights } \\
\text { Direct } \\
\text { employment }\end{array}$ \\
\hline
\end{tabular}

This study employs DEA to tourism industry in Sri Lanka considering the period from 1980 to 2018 and treating each year as individual decisionmaking unit. However, the data analysis is mainly divided in to two segments where the first segment covers the period from 1980 to 2009 while the second segment of the analysis covers the period from 2010 to 2018. The inputs and outputs used in this study are illustrated in Table 1.

All item tourist price index, number of hotel rooms, number of beds, and tourist arrivals were treated as inputs into different DEA models while tourism receipts, foreign guest nights and direct employment generation were considered as outputs in different DEA specifications and these models are estimated allowing for 


\section{Original Article}

different input - outputs combinations. Table 2 provides such combinations of inputs and outputs that are used in order to capture the variety of dimensions of tourism industry in terms of efficiency.

Table 2: Input - Output combinations considered for variety of DEA runs

\begin{tabular}{|c|c|c|}
\hline Model & Inputs & Outputs \\
\hline $\begin{array}{l}\text { DEA } \\
\text { Run } 1\end{array}$ & $\begin{array}{l}\text { Number of } \\
\text { Beds in } \\
\text { Hotels } \\
\text { International } \\
\text { Visitor } \\
\text { Arrivals } \\
\text { Tourist Price } \\
\text { Index }\end{array}$ & $\begin{array}{l}\text { Official } \\
\text { Tourism } \\
\text { Earning }\end{array}$ \\
\hline $\begin{array}{l}\text { DEA } \\
\text { Run } 2\end{array}$ & $\begin{array}{l}\text { Number of } \\
\text { Beds in } \\
\text { Hotels } \\
\text { International } \\
\text { Visitor } \\
\text { Arrivals } \\
\text { Tourist Price } \\
\text { Index }\end{array}$ & $\begin{array}{l}\text { Foreign } \\
\text { Guest } \\
\text { Nights }\end{array}$ \\
\hline $\begin{array}{l}\text { DEA } \\
\text { Run } 3\end{array}$ & $\begin{array}{l}\text { Number of } \\
\text { Beds in } \\
\text { Hotels } \\
\text { International } \\
\text { Visitor } \\
\text { Arrivals } \\
\text { Tourist Price } \\
\text { Index }\end{array}$ & $\begin{array}{l}\text { Direct } \\
\text { Employment }\end{array}$ \\
\hline $\begin{array}{l}\text { DEA } \\
\text { Run } 4\end{array}$ & $\begin{array}{l}\text { Number of } \\
\text { Beds in } \\
\text { Hotels } \\
\text { International } \\
\text { Visitor } \\
\text { Arrivals } \\
\text { Tourist Price } \\
\text { Index }\end{array}$ & $\begin{array}{l}\text { Official } \\
\text { Tourism } \\
\text { Earning } \\
\text { Foreign } \\
\text { Guest } \\
\text { Nights, } \\
\text { Direct } \\
\text { Employment }\end{array}$ \\
\hline
\end{tabular}

Analytical Framework: Data Envelopment Analysis

According to the objectives of the current study, non-parametric production frontier approach is proposed which generally used to evaluate the efficiency of firms or nonprofit organizations. This section concisely presents the DEA technique for efficiency evaluation. In order to estimate the efficiency of tourism sector, it is assumed that the tourism production technology can be characterized by a production frontier, which provides the maximum possible output given the proper inputs. The current study proposes the following production function for tourism sector in Sri Lanka.

Output of the Tourism $=$ $f$ (Inputs to the tourism industry).

A non-parametric DEA is used to manage multiple inputs and outputs whereas the functional form of the production function is completely not known in terms of technical perspective. The main advantage of the DEA over a parametric approach is that it does not require any rigorous assumption concerning the production technology, while DEA can also easily accommodate multiple outputs. DEA is a non-parametric linear programming method of measuring efficiency to assess a production frontier. The efficiency of tourism industry is evaluated against this frontier. In other words, following the Farrell's (1957) groundwork for nonparametric production frontiers, 


\section{Original Article}

different DEA models have been developed over the years. Charnes et al. (1978) proposed the basic model that had an input orientation and assumed constant returns to scale (CRS). Subsequently, Banker et al. (1984) considered variable returns to scale (VRS) as an alternative assumption. Comprehensive treatments of the methodology and empirical applications are evidenced by hundreds of publications. Cooper et al. (2007), Fried et al. (2008), and Emrouznejad et al. (2008) have provided some of the theoretical developments as well as the important empirical applications of DEA in efficiency evaluation context.

The current study employs the outputoriented framework that gives the maximum quantity of output which can be acquired when the inputs are considered to be fixed. This assumption is realistic since the appraisals of performance are conducted under a given set of inputs. Banker et al. (1984) expanded the ratio concept of the CCR model, making both Farrell's model and the CCR model. It treated the assumption that the zero efficiency in the constant returns to scale (CRS) could be caused by the improper scale instead of nontechnical efficiency. Therefore, the BCC model assumes the variable returns to scale (VRS), in which the technical efficiency is divided into the pure technical efficiency and the scale efficiency in order to measure the efficiency and the returns to scale. The scale efficiency is the result of the pure technical efficiency of the BCC model divided by the technical efficiency of the CCR model.

The CCR - DEA model measures technical efficiency of a firm relative to a reference technology exhibiting constant returns to scale (CRS) everywhere on the production frontier. This, of course, is rather restrictive because it is unlikely that CRS will hold globally in many realistic cases. As a result, the CCR-DEA model should not be applied in a wide variety of situations. In an important extension of this approach, Banker et al. (1984) generalized the original DEA model for technologies exhibiting increasing, constant, or diminishing returns to scale at different points on the production frontier.

The assumption of VRS as opposed to CRS affects the values of the efficiency scores of the DMUs. It should be noted that the set of DMUs identified as inefficient under VRS will be the same whether an input- or output-oriented approach is taken. The value of the efficiency score of an inefficient DMU, however, will vary with the choice of approach (either input- or outputoriented). Under VRS the following linear programming problem must be solved. 


\section{Original Article}

Maximize $\quad \phi_{k}+\varepsilon \sum_{r=1}^{s} s_{r}+\varepsilon \sum_{i=1}^{m} s_{i}$

Subject to;

$\phi_{k} y_{r k}-\sum_{j=1}^{n} \lambda_{j} y_{r j}+s_{r}=0 \quad r=1(1) S$

$X_{i k-} \sum_{j=1}^{n} \lambda_{j} x_{i j}-s_{i}=0 \quad i=1(1) m$

$\sum_{j=1}^{n} \lambda_{j}=1$

$\lambda_{j}, s_{r}, s_{i} \geq 0 \quad \forall j=1(1) n ; \quad r=1(10 s ; \quad i=1(1) m$

Where there are $s$ outputs and $m$ inputs; $y_{r k}$ is the amount of output $r$ produced by DMU $\mathrm{k} ; x_{i k}$ is the amount of input $i$ used by $\mathrm{k}^{\text {th }}$ DMU, $s_{r}$ and $s_{i}$ are represented output and input slacks respectively, and $\lambda_{j}$ represents the proportion of the factor weight in all the evaluated DMU. The epsilon $(\varepsilon)$ is an infinitesimally small positive number (selected by the researcher). Finally, the efficiency measure obtained would not be invariant to the numerical value of $\varepsilon$ chosen by the analyst.

Overall technical efficiency of DMU $k$ is measured by $T E_{k}=1 / \phi_{k}$ (in the output-oriented framework) or $T E_{k}=\theta_{k} \quad$ (in the input-oriented framework) and scale efficiency can be identified by calculating the following ratio for DMU $k$ :

$$
S C E_{k}=\frac{T E_{k},{ }_{C R S}}{T E_{k}, V R S}
$$

\section{EMPIRICAL RESULTS}

This paper proposed a simple framework for the evaluation of performance of tourism industry in Sri Lanka in terms of technical efficiency and scale efficiency. The approach was entirely depended on the nonparametric piece-wise production frontier approach. The analysis portrayed multiple inputs and multiple outputs while single output DEA models were also estimated for more elaborated discussion. All the proposed DEA models were estimated using the slack based multi - stage DEA estimation procedure. The summary of the technical efficiency estimates for both segments illustrated in Table 3. Scale efficiency as well as the economies of scales is also presented in Table 3 as additional information for supporting to the efficiency analysis. 
Table 3: Summary of efficiency analysis

\begin{tabular}{|c|c|c|c|c|}
\hline \multirow[t]{2}{*}{ Item } & \multicolumn{2}{|c|}{$\begin{array}{l}\text { Technical } \\
\text { efficiency }\end{array}$} & \multicolumn{2}{|c|}{ Scale efficiency } \\
\hline & $\begin{array}{l}1980- \\
2009\end{array}$ & $\begin{array}{l}2010- \\
2018\end{array}$ & $\begin{array}{l}1980- \\
2009\end{array}$ & $\begin{array}{l}2010- \\
2018\end{array}$ \\
\hline $\begin{array}{l}\text { DEA } \\
\text { Model_1 }\end{array}$ & 0.644 & 0.783 & $\begin{array}{l}0.604 \\
(\text { IRS })^{3}\end{array}$ & $\begin{array}{l}0.788 \\
\text { (IRS) }\end{array}$ \\
\hline $\begin{array}{l}\text { DEA } \\
\text { Model_2 }\end{array}$ & 0.621 & 0.741 & $\begin{array}{l}0.836 \\
(\mathrm{DRS})\end{array}$ & $\begin{array}{l}0.899 \\
\text { (IRS) }\end{array}$ \\
\hline $\begin{array}{l}\text { DEA } \\
\text { Model_3 }\end{array}$ & 0.690 & 0.799 & $\begin{array}{l}0.779 \\
\text { (DRS) }\end{array}$ & $\begin{array}{l}0.876 \\
\text { (IRS) }\end{array}$ \\
\hline $\begin{array}{l}\text { DEA } \\
\text { Model_4 }\end{array}$ & 0.785 & 0.889 & $\begin{array}{l}0.955 \\
\text { (IRS) }\end{array}$ & $\begin{array}{l}0.989 \\
\text { (IRS) }\end{array}$ \\
\hline
\end{tabular}

Source: Author's Calculations through data analysis

The model DEA_2 was obtained by replacing the number of beds in hotels by number of hotel rooms and the efficiency results were identical with the model DEA_1 and hence considered these two models as a single model. When official tourism receipts are taken as the output of the industry (in models DEA_1 and DEA_2), the tourism industry has achieved 78 per cent of efficiency on average for the post war period with compared to 64 percent during the war period and thus input slacks are observed for inputs of number of beds in hotels, international tourist arrivals and tourist prices in both segments of the industry. As shown in Table 3, scale efficiency is also less than the unity showing that tourism industry was not operating in its maximum potential in terms of economies of scale. According to the findings, tourism industry prevails IRS

\footnotetext{
${ }^{3}$ IRS stands for Increasing Returns to Scale and DRS stands for Decreasing Returns to Scale
}

(Increasing Returns to Scale) for the entire period from 2010 to 2018 considered for the study when the tourism industry represented in a single model. It gives some important fact that tourism industry is expanding by increasing its potential outcome than the increase of its inputs. Thus, there is a possibility to expand the tourism industry in terms of increasing potential tourism receipts. However, it has shown that there were no input slacks ${ }^{4}$ on arrivals but slacks on tourist prices started to increase for the last decade. It is evidenced that tourism prices explicitly affect performance of the industry.

It important to note that full model, DEA Model_4 is comparatively shows a higher level of performance of the tourism industry for the periods of war and post war compared to single output models. It is obvious that multiple outputs and multiple inputs depict the real operational behaviour of the industry. The lowest performance is evident in the case of tourism earnings as an output. The full model (DEA_4) is 89 per cent efficient on average and the scale efficiency is also higher (99 per cent) for the post war period and these figures are comparatively higher than the values in war period.

On the other end, the industry has been prevailing IRS (Increasing

\footnotetext{
${ }^{4}$ Slack computations are not included to the discussion as a table form since it consumes more space in the document.
} 
Returns to Scale) for all models in the post war period while just models DEA_1 and DEA_4 reveals same performance in war period. According to the theory of economics DRS in an industry is due to number of reasons such as increasing difficulties of management, coordination and control. However, these reasons may not be the case for tourism in Sri Lanka. Probably, graded tourist hotels and number of beds has grown within the time span considered for this study while foreign guest nights show a marginal increase compared to the increase of inputs into the industry. Major cause for this is due to the frequent uneven swings of arrivals with crucial setbacks such as Tsunami and terrorism over the three decades. For the modelsDEA_3 and DEA_4, tourist arrivals do not have input slacks while number of beds and tourist prices evidenced for slacks in the post war period. It means that tourist arrivals have not been reached its maximum potential and again tourist prices are significantly influencing to the industrial performance.

The model DEA_3 takes the direct employment generated by the tourism industry as the industry's output. It also shows that industry has been operated inefficiently because the mean efficiency level is 78 per cent while input slacks are observed within the period from 2009 to 2018. Finally, the DEA_4 is specified integrating all the three outputs, tourism receipts, foreign guest nights and direct employment generated, into a single model with similar inputs used. In this case the tourism industry was considered as an industry with multiple inputs and multiple outputs. It always takes into account these dimensions as important aspects of tourism industry. The findings reveal that industry has been operating inefficiently since mean efficiency score is 0.95 . The scale efficiency is also less than unity and industry reveal mixture of IRS and DRS for the war period while it reveals IRS for all models in post war period.

\section{SUMMARY AND CONCLUSIONS}

This empirical research evaluated the performance of tourism industry in Sri Lanka for the period from 1980 to 2018 in terms of technical efficiency. The sample period was separated in to two periods conserving the civil war prevailed for 30 years. The war period covers from 1980 t0 2009 and post war period covers from 2010 to 2018. Nonparametric production frontier approach was employed and accordingly different DEA models were formulated and efficiency was calculated using these models. Following conclusions summarized below can be drawn as per the findings of this study.

Tourism industry has not been reached its maximum potential in terms of performance in the industry in different dimensions within the two-time horizons considered though 
it has shown a higher level of performance in the post war period with compared to war period 5 . Number of beds in hotels is sufficient as inputs slacks were prevailed. This is evident with the occupancy ratio and it has been reported below the 50 per cent in its potential. Therefore, further investment on construction work in tourism sector is evidently wastage of resources. Some strategies need to implement to increase room occupancy rate. Further construction work needs realistic forecasts of arrivals where Sri Lanka Tourism Development Authority never utilised. Tourist receipts can be improved and thus need to formulate some policy initiatives that must focus the expenditure per tourist per day as well as to increase the average stay of tourists. Tourist prices directly affect the performance of the industry and hence need some strategies to maintain stable tourist prices on tourist products and services.

Overall performance of the tourism industry can be improved in terms of tourist earnings, employment generation and number of nights a tourist is staying in the country. Therefore, all policy implications must be addressed these issues not constructing many hotels or hotel rooms. Customized packages and promotions, discounts and loyalty programs, engage with guests, tie up with corporate are some guaranteed

\footnotetext{
${ }^{5}$ It is important to note that DEA efficiency scores are relative measures other than global measures.
}

recommendations for improving hotel occupancy rate in terms of foreign guest nights. It will help to resolve number of deficiencies in tourism industry in Sri Lanka.

This study limits its discussion just to investigate the level performance in terms of technical efficiency and thus the paper can be further improved overcoming this limitation. Future research can be extended to address the determinants of the performance of tourism industry based on these technical efficiency values.

\section{References}

Anderson, R.I., Fok, R., \& Scott, J. (2000). Hotel industry efficiency: an advanced linear programming examination. American Business Review, 18(1), 40-48.

Banker, R. D., Charnes, A. \& Cooper, W. W. (1984). Some models for estimating technical and scale efficiencies in data envelopment analysis. Management Science. 30(9), 1078-1092.

Barros, C.P. (2004). A stochastic cost frontier in the Portuguese hotel industry. Tourism Economics, 10(2), 177-192.

Barros, C. P. \& Mascarenhas, M. J. (2005). Technical and allocative efficiency in chain of small hotels. International Journal of Hospitality Management, 24, 415-436.

Bayrak, R. \& Bahar, O. (2018). Economic efficiency analysis of tourism sector in OECD countries: An empirical study with DEA. International Journal of Economic and Administrative Studies, 20. 83-100.

Chaabouni, S. (2019). China's regional tourism efficiency: A two-stage double bootstrap data envelopment analysis. Journal of Destination Marketing $\mathcal{E}$ Management, 11, 83-191. 
Chang, Ti-Yi \& Hwang, Shiuh-Nan (2003). Using data envelopment analysis to measure hotel managerial efficiency Chang in Taiwan. Tourism Management, 24(4), 357-369.

Charnes, A., Cooper, W. W. W. \& Rhodes, E. (1978). Measuring the efficiency of decision making units. European Journal of Operational Research, 2, 429 - 444.

Chen, C.F. (2007). Applying the stochastic frontier approach to measure hotel managerial efficiency in Taiwan. Tourism Management, 28, 696-702.

Cooper, W. M., Seiford, L. M. \& Tone, K. (2007). Data envelopment analysis: A comprehensive text with models, applications, references and DEA-solver software, (2nd ed.). New York: Kluwer Academic Publishers

Cracolicia, M. F., Nijkampb, P. \& Cuffaro, M. (2006). Efficiency and productivity of Italian tourist destinations: A quantitative estimation based on data envelopment analysis and the Malmquist method, Working papers, DOI from http://www.tinbergen.nl.

Emrouznejad, A., Parker, B. \& Tavares, G. (2008). Evaluation of research in efficiency and productivity: A survey and analysis of the first 30 years of scholarly literature in DEA. Journal of Socio-Economics Planning Science, 43(2), 151-157.

Farrell, M. J. (1957). The measurement of productive efficiency. Journal of Royal Statistical Society, 120, 253-281.

Fayissa, B. (2007). The impact of tourism on economic growth and development in Africa. Working papers, DOI from http://frank.mtsu.edu/berc/working/Tou rismAfricawp.pdf.

Fried, H. O., Lovell, C. A. K. \& Schmidt, S. S. (Ed.). (2008). The measurement of productive efficiency and productivity growth. New York: Oxford University Press.

Hadad, S., Hadad, Y., Malul, M., \& Rosenboim, M. (2012). The economic efficiency of the tourism industry: a global comparison. Tourism Economics, 18(5), 931-940.

Huang, C. W., Chiu, Y. H., Ting, C. T., \& Lin, C. H. (2011). Applying a hybrid DEA model to evaluate the influence of marketing activities to operational efficiency on Taiwan's international tourist hotels. Journal of the Operational Research Society, 63, 549-560.

Hwang, S. \& Chang, T. (2003). Using data envelopment analysis to measure hotel managerial efficiency change in Taiwan. Tourism Management, 24, 357-369.

Kreishan, F. M. M. (2010). Tourism and economic growth: The case of Jordan. European Journal of Social Sciences, 15(2), 229-234.

Manuela, P., Claudio, D. \& Antonello, P. (2010). An investigation into the relationship between size and efficiency of the Italian hospitality sector: A window DEA approach. European Journal of Operational Research, 204, 613620.

Morey, R. C. \& Dittman, D. A. (1995). Evaluating a hotel gm's performance: A case study in benchmarking. Cornell Hotel Restaurant and Administration Quarterly, 36(5), 30-35.

Pulina, M., Detotto, C. \& Paba, A. (2010). An investigation in to the relationship between size and efficiency of the Italian hospitality sector: A window DEA approach. European Journal of Operational Research, 204(3), 613-620.

Oliveira, R., Pedro, M. I., \& Marques, R. C. (2013). Efficiency and its determinants in Portuguese hotels in the Algarve. Tourism Management, 36, 641-649.

Reynolds, D. (2003). Hospitality-productivity assessment: Using data-envelopment analysis. Cornell Hotel Restaurant and Administration Quarterly, 44 (2), 130-137.

Simar, L., \& Wilson, P. W. (2007). Estimation and inference in two-stage, semiparametric models of production processes. Journal of Econometrics, 136(1), 31-64. 
Sri Lanka Tourism Development Authority. (2010-2017). Annual statistical report. Colombo: SLTDA.

Tisdell, Clement. (2013). Handbook of Tourism Economics - Analysis, New Applications and Case Studies. New York: World Scientific.

Soysal-Kurt, S. (2017). Measuring Tourism Efficiency of European Countries by Using Data Envelopment Analysis. European Scientific Journal, 13, 31-49.

Wang, Y.H., Lee, W.F., Wong, C.C. (2007). Productivity and efficiency analysis of international tourist hotels in Taiwan: an application of the stochastic frontier approach. Taiwan Economic Review 35, 87-114. 